\title{
Development of a Reliable Analytical Method for Liquid Anion-Exchange Extraction and Separation of Neodymium(III)
}

\author{
Balasaheb N. Kokare, ${ }^{1}$ Ganesh S. Kamble, ${ }^{2}$ Balasaheb M. Sargar, ${ }^{3}$ and Mansing A. Anuse ${ }^{2}$ \\ ${ }^{1}$ Department of Chemistry, Raje Ramrao Mahavidyalaya, Jath, Sangli 416 404, India \\ ${ }^{2}$ Analytical Chemistry Laboratory, Department of Chemistry, Shivaji University, Kolhapur 416 004, India \\ ${ }^{3}$ Analytical Chemistry Laboratory, PG Department of Chemistry, Jaysingpur College, Jaysingpur, Kolhapur 416 116, India
}

Correspondence should be addressed to Mansing A. Anuse, mansinganuse@yahoo.co.in

Received 24 October 2011; Accepted 1 December 2011

Academic Editor: Wan Kuen Jo

Copyright (c) 2012 Balasaheb N. Kokare et al. This is an open access article distributed under the Creative Commons Attribution License, which permits unrestricted use, distribution, and reproduction in any medium, provided the original work is properly cited.

The liquid-liquid extraction of neodymium(III) from succinate media $(0.06 \mathrm{M})$ has been studied at $\mathrm{pH} 6.0$ with the solution of $0.1 \mathrm{M}$ of $\mathrm{N}$ - $n$-octylaniline in xylene when equilibrium is maintained for $5 \mathrm{~min}$. The back-extraction of neodymium(III) has been performed by using $0.1 \mathrm{M} \mathrm{HClO}_{4}$. The effect of various parameters, such as $\mathrm{pH}$, equilibrium time, extractant concentration, stripping agents, organic diluents, and aqueous to organic volume ratio on the extraction of neodymium(III) has been studied. On the basis of slope analysis, the stoichiometry of the extracted species was determined as $1: 1: 2\left[\mathrm{RR}^{\prime} \mathrm{NH}_{2}{ }^{+} \mathrm{Nd}(\text { succinate })_{2}{ }^{-}\right]_{(\text {org })}$. The method is free from interference of large number cations and anions. The method was used for the selective extraction of neodymium(III) from its binary mixture with $\mathrm{U}(\mathrm{VI}), \mathrm{Zr}(\mathrm{IV}), \mathrm{Nb}(\mathrm{V}), \mathrm{La}(\mathrm{III}), \mathrm{Th}(\mathrm{IV}), \mathrm{Ce}(\mathrm{IV})$, and $\mathrm{Y}(\mathrm{III})$. The proposed method is selective and was successfully applied to the synthetic mixtures to show the practical utility of the extractant.

\section{Introduction}

Neodymium is never found in nature as the free element; rather, it occurs in ores such as monazite sand and bastnasite (40 ppm by weight) [1] that contain small amounts of all the rare earth metals. Neodymium can also be found in misch metal; it is difficult to separate from other rare earth elements.

Neodymium magnets are the strongest permanent magnets known: $\mathrm{Nd}_{2} \mathrm{Fe}_{14} \mathrm{~B}$ [2]. Neodymium magnets appear in the products such as microphones, professional loudspeakers, inear headphones, guitar and bass guitar pick-ups, and computer hard disc where low-mass small volume or strong magnetic fields are required. It exists in two allotropic forms [3]. Neodymium colours glass in delicate shades ranging from pure violet through wine-red and warm gray. Neodymium salts are used as a colourant for enamels. Probably because of similarities to $\mathrm{Ca}(\mathrm{II}), \mathrm{Nd}(\mathrm{III})$ has been reported to promote plant growth [4]. Rare-earth-element compounds are frequently used in China as fertilizers. Samarium-Neodymium dating is useful for determining the age relationship of rocks and meteorites. Certain transparent materials with a small concentration of neodymium ion can be used in laser as gain media for infrared wavelengths. Neodymium compounds are of low- to moderate-toxicity. Neodymium dusts and salts are very irritating to the eye, mucous membranes, and moderately irritating to skin. Breathing the dust can cause lung embolisms and accumulated exposure damages the liver. It also acts as an anticoagulant especially when given intravenously.

Solvent extraction is one of the efficient methods for separation technology because of its simplicity, speed and applicability to both tracer and macro amounts of metal ions. As there are a number of different solvent extraction systems that could be used for metal ions separation, synergistic extraction systems have received attention for a long time. The synergistic solvent extraction of multicharged transition ions as well as lanthanide and actinide ions has been extensively studied using various chelating or complexing agents such as $\beta$-diketones, high-molecular-weight amines, amine salts, crown ethers, quaternary ammonium salts- and phosphorus-containing compounds, as synergists. It has been 


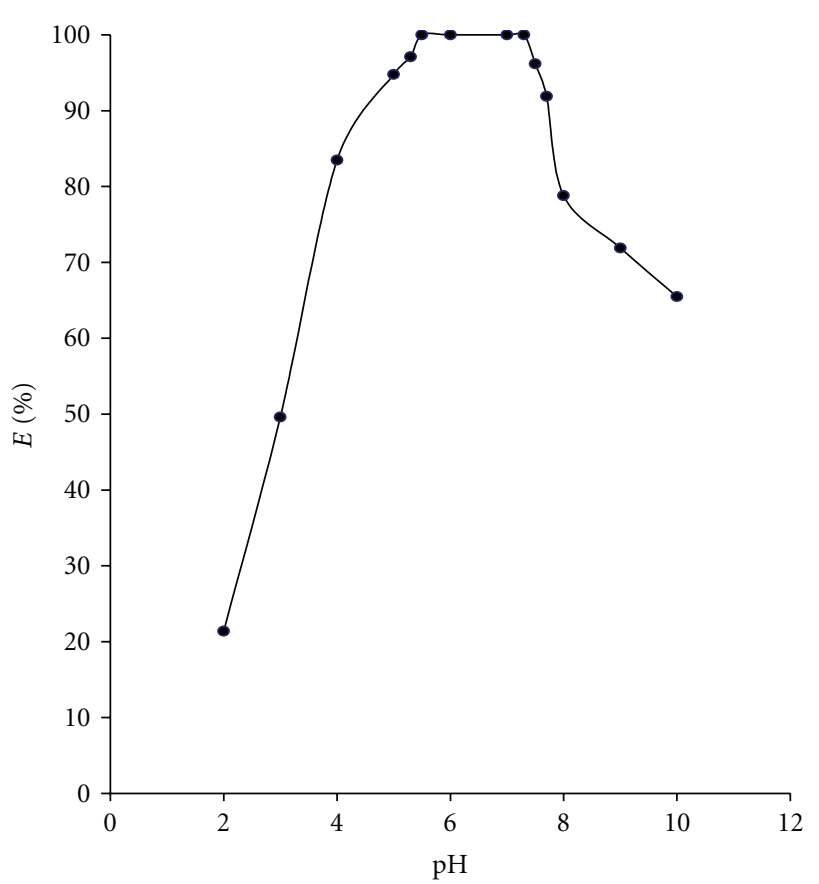

FIGURE 1: Extraction behaviour of neodymium(III) as a function of $\mathrm{pH}$ at $0.06 \mathrm{M}$ sodium succinate; $0.1 \mathrm{M} \mathrm{N}$ - $n$-octylaniline in xylene.

found that the metal ions can be extracted synergistically with considerable enhancement [5]. A systematic study of the synergistic solvent extraction and separation of neodymium(III) with 1-phenyl-3-methyl-4-benzoyl pyrazol-5-one in the presence of the quaternary ammonium salt, aliquat 336 [5, 6], 4-benzoyl-3-phenyl-5-isoxazolone alone and quaternary ammonium salt, aliquat 336 [7], bis(2,4,4,-trimethylpentyl) dithiophosphinic acid and trialkylphosphine oxide [8] were studied. However, methods require more than $1 \mathrm{~h}$ equilibration time for the quantitative extraction. Extraction behavior of neodymium(III) with some selected substituted malonamides $[9,10], n$ octyl(phenyl)- $N$ - $N$-diisobutylcarbamoyl methylphosphine oxide and mixed solvent using amino polyacetic acid and diethylene triamine pentaacetic acid nitrate solution [11], a mixture of calyx[4]arene carboxyl derivative and primary amine N1923 [12] has been investigated. Extraction depends on the concentration of salting out agents. A synergistic solvent extraction of neodymium(III) with thenoyltrifluoroacetone and aliquat $336[13,14]$, mixture of di-(2-ethylhexyl) phosphoric acid and S-octylphenoxyacetic acid [15], PC88A, and saponified PC88A [16] have been studied. The extraction was carried from mineral acid media; hence the methods are not eco-friendly. A separation process of neodymium(III) by liquid-liquid extraction with bis(2-ethylhexyl) phosphinic acid [17] was investigated. The 10 stages of extraction followed by 5 stages of scrubbing were considered.

There are very few methods reported for neodymium(III) by using high-molecular-weight amine. Extraction of trivalent neodymium by high-molecular-weight amine such as decylamine [18] from 0.5 to $3 \mathrm{M}$ nitric acid solution containing potassium phosphotungstate has been

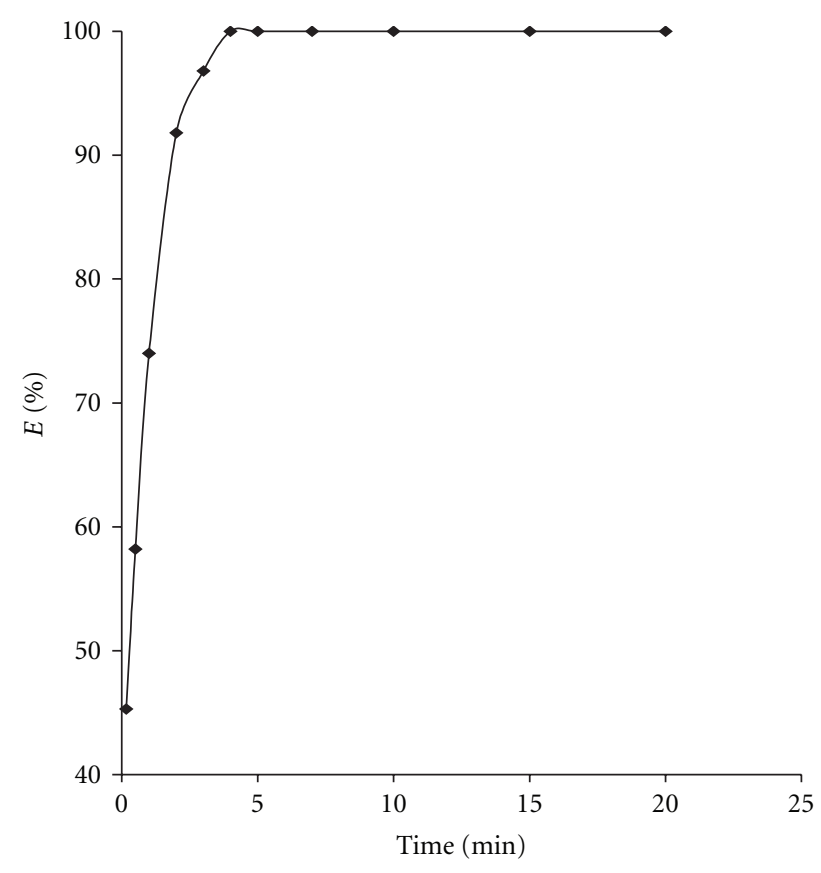

FIgURE 2: Effect of equilibration time on the extraction of neodymium(III) from $0.06 \mathrm{M}$ sodium succinate at $\mathrm{pH} 6.0 ; 0.1 \mathrm{M} \mathrm{N}-n$ octylaniline in xylene.

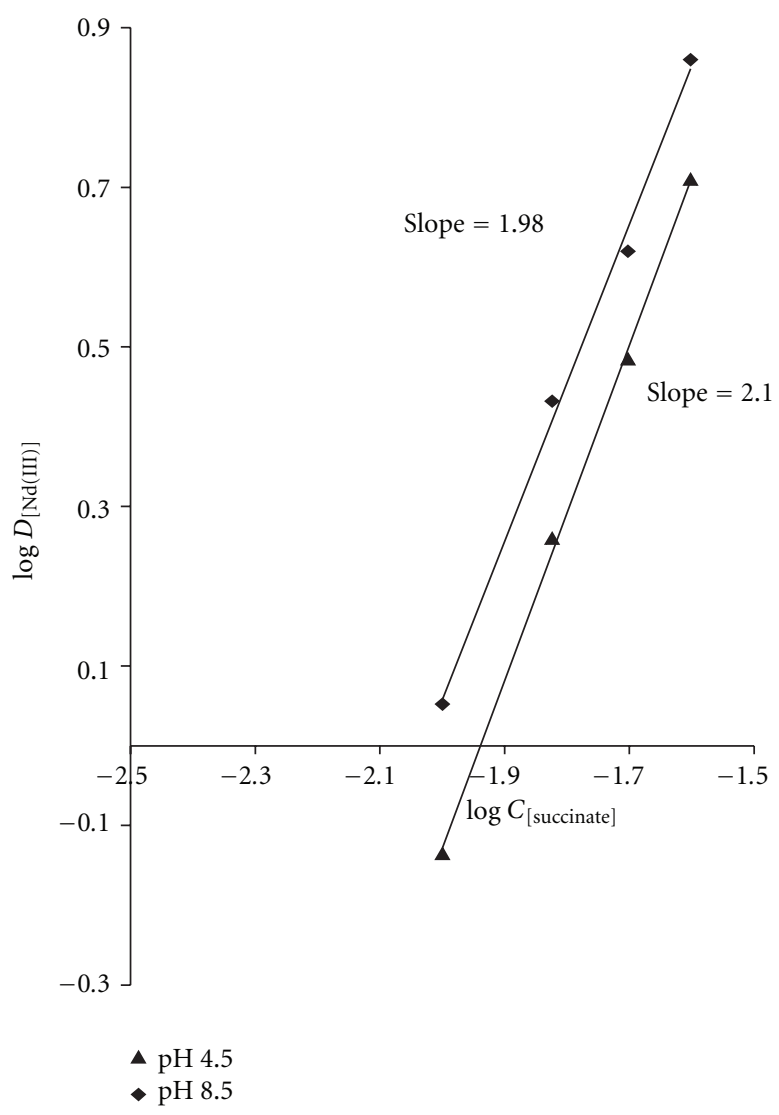

FIgUre 3: Log-log plot of $\log \mathrm{D}_{[\mathrm{Nd}(\mathrm{III})]}$ versus $\log \mathrm{C}_{\text {[Succinate] }}$ at $0.1 \mathrm{M}$ $\mathrm{N}$ - $n$-octylaniline with $\mathrm{pH} 4.5$ and $\mathrm{pH} 8.5$. 
TABLE 1: Extraction behavior of neodymium(III) as a function of $\mathrm{N}$ $n$-octylaniline concentration. $\mathrm{Nd}(\mathrm{III})=60 \mu \mathrm{g}$, sodium succinate $=$ $0.06 \mathrm{M}, \mathrm{pH}=6.00 \mathrm{Aq}:$ Org $=25: 10$, strippant $=0.1 \mathrm{M} \mathrm{HClO}_{4}(2 \times$ $5 \mathrm{~mL}$ ), equilibrium time $=5 \mathrm{~min}$.

\begin{tabular}{lcc}
\hline $\begin{array}{l}\text { N- } n \text {-octylaniline } \\
(M)\end{array}$ & $\begin{array}{c}\text { Percentage } \\
\text { extraction }(\% E)\end{array}$ & $\begin{array}{c}\text { Distribution } \\
\text { ratio }(D)\end{array}$ \\
\hline 0.00 & 0.00 & 0.00 \\
0.005 & 34.4 & 1.31 \\
0.01 & 43.4 & 1.92 \\
0.02 & 67.1 & 5.10 \\
0.03 & 74.6 & 7.34 \\
0.05 & 81.0 & 10.65 \\
0.07 & 91.8 & 27.99 \\
0.08 & 97.7 & 106.19 \\
0.09 & 100 & $\infty$ \\
0.1 & 100 & $\infty$ \\
0.2 & 100 & $\infty$ \\
0.3 & 100 & $\infty$ \\
0.5 & 100 & $\infty$ \\
\hline
\end{tabular}

investigated. Desai and Shinde reported liquid anion exchange extraction and separation of neodymium(III) from sodium succinate solution with tri- $n$-octylamine [19]. However, the method requires high reagent concentration in order to ensure the complete extraction. In this communication, systematic studies on the extractive properties of $\mathrm{N}-n$-octylaniline in xylene from succinate media have been proposed.

\section{Experimental}

2.1. Apparatus. An Elico digital spectrophotometer model SL-171 with $1 \mathrm{~cm}$ quartz cells was used for absorbance measurements. $\mathrm{pH}$ measurements were carried out using an Elico digital $\mathrm{pH}$ meter model LI- 120.

Glass vessels were cleaned by soaking in acidified solution of potassium dichromate followed by washing with soap and water, and rinsed two times with water.

All the apparatus were used during the time period from May 2009 to July 2009.

\subsection{Reagents}

2.2.1. Standard Neodymium(III) Solution. The stock solution of neodymium(III) was prepared by dissolving $0.294 \mathrm{~g}$ of neodymium oxide in $10 \mathrm{~mL}$ of perchloric acid and diluted with $250 \mathrm{~mL}$ of water. The solution was standardized [20] and working solution was prepared as required $(60 \mu \mathrm{g} / \mathrm{mL})$ by appropriate dilution of the stock solution.

2.2.2. 4-(2-Pyridylazo)-Resorcinol (PAR) Solution (0.05\% $w / v)$. A $0.05 \%$ aqueous solution of 4-(2-pyridylazo)-resorcinol was prepared in water and used for the spectrophotometric determination of neodymium(III).
2.2.3. $\mathrm{N}$-n-Octylaniline. The extractant $\mathrm{N}$ - $n$-octylaniline was prepared by the method of Gardlund et al. [21] and its solutions were prepared in xylene. All other chemicals used in this work were of AR grade. Double distilled water was used throughout the work.

2.2.4. General Extraction and Determination Procedure for Neodymium(III). An aliquot of $60 \mu \mathrm{g}$ neodymium(III) solution was mixed with a sufficient quantity of sodium succinate $(0.41 \mathrm{~g})$ to make its concentration $0.06 \mathrm{M}$ in a total volume of $25 \mathrm{~mL}$ of the solution. The $\mathrm{pH}$ of the aqueous solution was adjusted from 6.0 to 7.5 by dilute sodium hydroxide and perchloric acid solution. The solution was then transferred to a $125 \mathrm{~mL}$ separating funnel and shaken with $10 \mathrm{~mL}$ of $0.1 \mathrm{M}$ $\mathrm{N}$-n-octylaniline in xylene for $5 \mathrm{~min}$. After separating the two phases, the aqueous phase was discarded and the organic phase was stripped with $2 \times 5 \mathrm{~mL}$ portions of $0.1 \mathrm{M}$ perchloric acid solution. The stripped aqueous phase was equilibrated with $5 \mathrm{~mL}$ of xylene to remove the traces of dissolved amine and evaporated to moist dryness. The slightly acidic solution was transferred to a $25 \mathrm{~mL}$ volumetric flask followed by $1 \mathrm{~mL}$ of $0.05 \%$ 4-(2-pyridylazo)-resorcinol solution, the $\mathrm{pH}$ was adjusted to 6.00 with dilute sodium hydroxide and perchloric acid solution. The solution was diluted to $25 \mathrm{~mL}$ with distilled water and the absorbance after $30 \mathrm{~min}$ of orange-red complex at $515 \mathrm{~nm}$ read was spectrophotometrically [22] against the reagent blank in the reference cell. The amount of neodymium(III) in the solution was calculated from the calibration curve.

\section{Results and Discussion}

3.1. Extraction as a Function of $p H$. The extraction of neodymium(III) was ascertained by carrying out the $\mathrm{pH}$ range between $\mathrm{pH} 1-10$ with a $0.1 \mathrm{M}$ solution of $\mathrm{N}$ - $n$-octylaniline in xylene at fixed concentration of $0.06 \mathrm{M}$ sodium succinate. The $\mathrm{pH}$ for the quantitative extraction was 5.5-7.3 with $\mathrm{N}$ $n$-octylaniline. Hence, the extraction of neodymium(III) was carried out at pH 6.0 for further studies (Figure 1).

3.2. Effect of the $N$-n-Octylaniline Concentration. Extraction of neodymium(III) was carried out by varying the reagent concentration from $0.005-0.5 \mathrm{M}$ of $\mathrm{N}$ - $n$-octylaniline in $\mathrm{xy}$ lene. It was observed that the extraction increased with increases in the concentration of extractant. The obtained result is shown in Table 1 . Therefore, the optimum concentration of the extractant selected was $0.1 \mathrm{M} \mathrm{N}$ - $n$-octylaniline in xylene.

3.3. Effect of Weak Organic Acid Concentration. The extraction of neodymium(III) was examined at $\mathrm{pH} 6.0$ with $0.1 \mathrm{M}$ $\mathrm{N}$ - $n$-octylaniline in xylene in the presence of varying concentrations from 0.005 to $0.1 \mathrm{M}$ of various weak organic acids (Table 2). The extraction of ion-pair complex of neodymium(III) was found to be quantitative in the range of $0.05-$ $0.07 \mathrm{M}$ sodium succinate. Hence, $0.06 \mathrm{M}$ concentration of sodium succinate was used for further studies. While incomplete extraction of neodymium(III) was found to be in 
TABLE 2: Extraction behaviour of neodymium(III) as a function of organic acid concentration. $\mathrm{Nd}(\mathrm{III})=60 \mu \mathrm{g}, \mathrm{pH}=6.0, \mathrm{~N}-n$-octylaniline $=$ $0.1 \mathrm{M}$ in xylene $(10 \mathrm{~mL}), \mathrm{Aq}: \mathrm{Org}=25: 10$, strippant $=0.1 \mathrm{M} \mathrm{HClO}_{4}(2 \times 5 \mathrm{~mL})$, equilibrium time $=5 \mathrm{~min}$.

\begin{tabular}{|c|c|c|c|c|c|c|c|c|}
\hline \multirow{2}{*}{ Acid $(M)$} & \multicolumn{2}{|c|}{ Sodium salicylate } & \multicolumn{2}{|c|}{ Sodium succinate } & \multicolumn{2}{|c|}{ Sodium malonate } & \multicolumn{2}{|c|}{ Ascorbic acid } \\
\hline & $\% E^{\mathrm{a}}$ & $D^{\mathrm{b}}$ & $\% E^{\mathrm{a}}$ & $D^{\mathrm{b}}$ & $\% E^{\mathrm{a}}$ & $D^{\mathrm{b}}$ & $\% E^{\mathrm{a}}$ & $D^{\mathrm{b}}$ \\
\hline 0.005 & 13.6 & 0.39 & 24.6 & 0.815 & 20.0 & 0.63 & 9.3 & 0.25 \\
\hline 0.01 & 33.0 & 1.23 & 42.6 & 1.85 & 31.0 & 1.12 & 17.5 & 0.47 \\
\hline 0.02 & 47.2 & 2.23 & 57.4 & 3.36 & 52.8 & 2.80 & 27.0 & 0.93 \\
\hline 0.03 & 57.1 & 3.33 & 82.0 & 11.38 & 61.7 & 4.03 & 36.8 & 1.45 \\
\hline 0.04 & 67.2 & 5.12 & 94.8 & 45.57 & 78.0 & 8.86 & 46.7 & 2.19 \\
\hline 0.05 & 83.2 & 12.38 & 100 & $\infty$ & 85.0 & 9.66 & 61.7 & 4.03 \\
\hline 0.06 & 88.4 & 19.10 & 100 & $\infty$ & 89.0 & 20.23 & 69.3 & 5.64 \\
\hline 0.07 & 85.2 & 14.39 & 100 & $\infty$ & 92.5 & 30.83 & 77.4 & 8.56 \\
\hline 0.08 & 81.4 & 10.94 & 97.1 & 83.7 & 83.2 & 12.38 & 83.5 & 12.65 \\
\hline 0.09 & 78.6 & 9.18 & 96.2 & 62.30 & 76.8 & 8.27 & 63.5 & 4.35 \\
\hline 0.1 & 72.2 & 6.49 & 92.5 & 30.83 & 75.1 & 7.54 & 58.8 & 3.56 \\
\hline 0.2 & 66.3 & 4.92 & 83.2 & 12.38 & 67.5 & 5.19 & 53.0 & 2.82 \\
\hline
\end{tabular}

${ }^{\mathrm{a}}$ Percentage extraction, bdistribution ratio.

TABLE 3: Extraction behaviour of neodymium(III) as a function of diluents. $\mathrm{Nd}(\mathrm{III})=60 \mu \mathrm{g}$, sodium succinate $=0.06 \mathrm{M}, \mathrm{pH}=6.0$, Aq: $\operatorname{Org}=25: 10$, strippant $=0.1 \mathrm{M} \mathrm{HClO}_{4}(2 \times 5 \mathrm{~mL})$, and equilibrium time $=5 \mathrm{~min}$.

\begin{tabular}{lccc}
\hline Solvent & $\begin{array}{c}\text { Dielectric } \\
\text { constant, } \varepsilon\end{array}$ & $\begin{array}{c}\text { Percentage } \\
\text { extraction } \\
(\% E)\end{array}$ & $\begin{array}{c}\text { Distribution } \\
\text { ratio }(D)\end{array}$ \\
\hline Benzene & 2.28 & 100 & $\infty$ \\
Toluene & 2.38 & 89.0 & 20.22 \\
Xylene & 2.30 & 100 & $\infty$ \\
Kerosene & 1.80 & 63.5 & 4.34 \\
Carbon tetrachloride & 2.24 & 82.3 & 11.62 \\
Chloroform & 4.40 & 89.9 & 22.25 \\
Amyl alcohol & 13.90 & 74.8 & 8.82 \\
1,2-Dichloroethane & 10.5 & 68.4 & 5.41 \\
MIBK & 13.11 & 69.6 & 5.70 \\
$n$-Butanol & 17.8 & 81.4 & 10.94 \\
\hline
\end{tabular}

sodium salicylate, sodium malonate, and ascorbic acid media.

3.4. Effect of Diluents. Various aromatic and aliphatic organic solvents were studied as diluents for $\mathrm{N}$ - $n$-octylaniline (Table 3). It was found that the extraction of neodymium(III) was quantitative only with benzene and xylene as diluents for $\mathrm{N}$ - $n$-octylaniline. Xylene was preferred as diluent, because it provides better phase separation. Hence, $0.1 \mathrm{M} \mathrm{N}$ - $n$-octylaniline in xylene was used in all the studies.

3.5. Effect of Equilibration Time. The extraction of neodymium(III) was studied for various periods of equilibration from 0.16 to $20 \mathrm{~min}$ with $\mathrm{N}$ - $n$-octylaniline. It was observed that, under the given experimental conditions, a minimum
4 min time was required for attaining the imitating extraction. It was checked that prolonged shaking time does not affect the extraction of neodymium(III). Hence, in all other studies the phase was equilibrated for 5 min (Figure 2).

3.6. Nature of Extracted Species. An attempt was made to ascertain the nature of extracted species of neodymium(III) with the extractant using slope-ratio method. The distribution ratio of neodymium(III) evaluated at different concentration in molar of succinate was used at fixed $\mathrm{N}-n$ octylaniline concentration at $\mathrm{pH} 4.5$ and $\mathrm{pH}$ 8.5. A graph of $\log \mathrm{D}_{[\mathrm{Nd}(\mathrm{III})]}$ versus $\log \mathrm{C}_{\text {[succinate }}$ gave a slope of 1.98 and 2.10, respectively, (Figure 3 ). Similarly, a plot of $\log \log \mathrm{D}_{[\mathrm{Nd}(\mathrm{III})]}$ versus $\log \mathrm{C}_{[\mathrm{N} \text { - } n \text {-octylaniline] }}$ at a fixed $\mathrm{pH} 4.5$ and $\mathrm{pH} 8.5$ with $0.06 \mathrm{M}$ succinate gave slope of 1.06 and 1.12 , respectively, (Figure 4). This indicates a mole ratio of neodymium(III) to succinate acid as $1: 2$ and that of $\mathrm{N}$ - $n$-octylaniline as $1: 1$. Thus, the extracted species was calculated to be an ion association complex with the probable composition $1: 2: 1$ (metal: acid: extractant). The probable mechanism of extracted species is as follows:

$$
\begin{gathered}
\mathrm{RR}^{\prime} \mathrm{NH}_{(\text {org })}+\mathrm{H}^{+}{ }_{(\text {aq })}=\mathrm{RR}^{\prime} \mathrm{NH}_{2}{ }^{+}{ }_{(\text {org })} \\
\mathrm{Nd}^{3+}{ }_{(\text {aq. })}+2 \text { succinate }^{2-}{ }_{\text {(aq. })}=\left[\mathrm{Nd}(\text { succinate })_{2}\right]^{-}{ }_{(\text {aq. })} \\
\mathrm{RR}^{\prime} \mathrm{NH}_{2}{ }^{+}{ }_{\text {(org) }}+\left[\mathrm{Nd}(\text { succinate })_{2}\right]^{-}{ }_{\text {(aq. })} \\
=\left[\mathrm{RR}^{\prime} \mathrm{NH}_{2}{ }^{+} \mathrm{Nd}(\text { succinate })_{2}{ }^{-}\right]_{(\text {org })}
\end{gathered}
$$

3.7. Effect of Stripping Agent. Various strong acids such as hydrochloric acid, nitric acid, and perchloric acid sulphuric acid in the range of $0.01-0.2 \mathrm{M}$ were investigated as stripping agents for neodymium(III). The back-extraction or recovery from the organic phase achieved with perchloric acid was better from 0.09 to $0.12 \mathrm{M}$ after $5 \mathrm{~min}$ shaking (Table 4 ). 
TABLE 4: Extraction behaviour of neodymium(III) as a function of stripping agents. $\mathrm{Nd}(\mathrm{III})=60 \mu \mathrm{g}$, sodium succinate $=0.06 \mathrm{M}$, $\mathrm{pH}=6.0$, equilibrium time $=5 \mathrm{~min}$, Aq. $:$ Org $=25: 10 \mathrm{~N}$ - $n$-octylaniline $=0.1 \mathrm{M}$ in xylene, strippant $=(2 \times 5 \mathrm{~mL})$.

\begin{tabular}{lcccc}
\hline Acid & $\begin{array}{c}\mathrm{HCl} \\
\text { Recovery } \\
(\%)\end{array}$ & $\begin{array}{c}\mathrm{HClO}_{4} \\
\text { Recovery } \\
(\%)\end{array}$ & $\begin{array}{c}\mathrm{HNO}_{3} \\
\text { Recovery } \\
(\%)\end{array}$ & $\begin{array}{c}\mathrm{H}_{2} \mathrm{SO}_{4} \\
\text { Recovery } \\
(\%)\end{array}$ \\
\hline 0.005 & 47.0 & 65.7 & 55.8 & 34.9 \\
0.01 & 54.6 & 73.2 & 57.9 & 42.6 \\
0.03 & 67.5 & 80.5 & 68.6 & 49.3 \\
0.05 & 69.3 & 89.3 & 79.7 & 63.7 \\
0.07 & 76.7 & 98.3 & 80.3 & 62.2 \\
0.09 & 80.3 & 100 & 81.0 & 60.1 \\
0.1 & 82.2 & 100 & 85.9 & 74.8 \\
0.15 & 87.3 & 100 & 72.0 & 53.9 \\
0.2 & 85.7 & 100 & 67.3 & 47.8 \\
0.3 & 80.2 & 92.6 & 65.9 & 43.6 \\
0.5 & 73.5 & 83.9 & 61.2 & 29.3 \\
0.7 & 67.9 & 78.8 & 57.4 & 23.4 \\
1.0 & 63.5 & 75.3 & & 23.5 \\
\hline
\end{tabular}

Water-recovery $62.5 \%$, acetate buffer $(1)(\mathrm{pH}=3.42)$ : recovery $55.8 \%,(2)(\mathrm{pH}=5.57)$ : recovery $63.4 \%$.

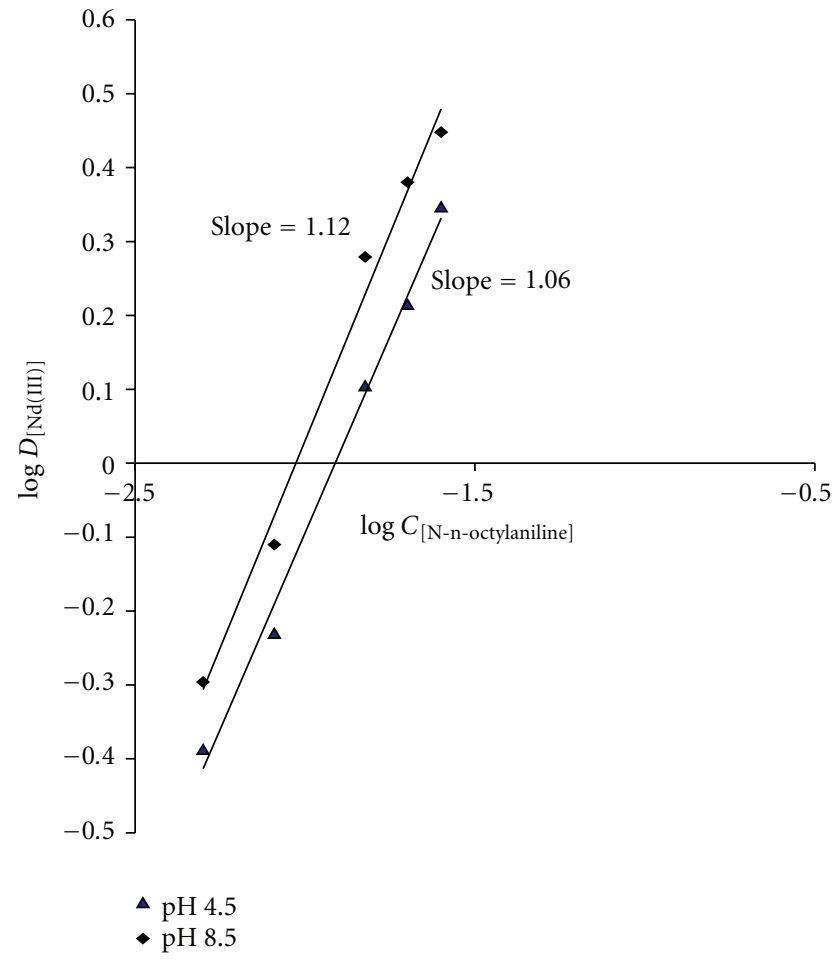

Figure 4: Log-log plot of $\log \mathrm{D}_{[\mathrm{Nd}(\mathrm{III})]}$ versus $\log \mathrm{C}_{[\mathrm{N}-n-\text { octylaniline }]}$ at $0.06 \mathrm{M}$ sodium salicylate with $\mathrm{pH} 4.5$ and $\mathrm{pH} 8.5$.

In this work $2 \times 5 \mathrm{~mL}$ portions of $0.1 \mathrm{M}$ perchloric acid were used as a suitable strippant.

3.8. Effect of Diverse Ions. The effect of various cations and anions on the recovery of neodymium(III) was investigated. The tolerance limit was set as the amount of foreign ions causing a change $\pm 2 \%$ error in the recovery of neodymium(III). Initially the foreign ion was added to the neodymium(III) solution in large excess, $100 \mathrm{mg}$ for anions, and $25 \mathrm{mg}$ for cations. However, interference due to vana$\operatorname{dium}(\mathrm{V})$ and zirconium(IV) was eliminated by masking with $3 \mathrm{mg}$ of $\mathrm{F}^{-}$. Manganese(V) was masked with $5 \mathrm{mg}$ of oxalate. The anions such as EDTA and citrate were interfered in the extraction of neodymium(III) by the proposed method (Table 5).

\section{Applications}

4.1. Separation and Determination of Neodymium(III) from Binary Mixture. The separation of neodymium(III) from some commonly associated metal ions like U(VI), Th(IV), $\mathrm{Nb}(\mathrm{V}), \mathrm{Zr}(\mathrm{IV}), \mathrm{Y}(\mathrm{III}), \mathrm{La}(\mathrm{III})$, and $\mathrm{Ce}(\mathrm{IV})$ using N-n-octylaniline was achieved by taking advantage of the difference in the extraction conditions of metal such as $\mathrm{pH}$ of the aqueous phase, reagent concentration and use of masking agent (Table 6).

Neodymium(III) was separated from U(VI), Th(IV), $\mathrm{Nb}(\mathrm{V}), \mathrm{Zr}(\mathrm{IV})$, and $\mathrm{La}(\mathrm{III})$ by its extraction with $10 \mathrm{~mL}$ of $0.1 \mathrm{M} \mathrm{N}$-n-octylaniline in xylene from $0.06 \mathrm{M}$ sodium succinate. Under this condition, the added metal ions remained quantitatively in the aqueous phase. The aqueous phase was washed with $5 \mathrm{~mL}$ xylene to remove traces of the reagent. Metal ions from the aqueous phase were determined by standard methods [20, 23-25] while neodymium(III) was determined by the proposed method after backstripping the organic phase.

Similarly neodymium(III) was separated from Ce(IV) and $\mathrm{Y}$ (III) by masking with $10 \mathrm{mg}$ fluoride and $50 \mathrm{mg}$ thiosulphate, respectively. The masked $\mathrm{Ce}(\mathrm{IV})$ and $\mathrm{Y}(\mathrm{III})$ remained in the aqueous phase quantitatively under the optimum extraction condition of neodymium(III). After 
TABLE 5: Effect of various diverse ions. $\mathrm{Nd}(\mathrm{III})=60 \mu \mathrm{g} \mathrm{pH}=6.00$, sodium succinate $=0.06 \mathrm{M}$, Aq: Org $=25: 10, \mathrm{~N}$ - $n$-octylaniline $=$ $0.1 \mathrm{M}$ in xylene $(10 \mathrm{~mL})$, equilibrium time $=5 \mathrm{~min}$, and strippant $=$ $0.1 \mathrm{M} \mathrm{HClO}_{4}(2 \times 5 \mathrm{~mL})$.

\begin{tabular}{|c|c|c|}
\hline $\begin{array}{l}\text { Ratio of } \\
\text { added ions } \\
\text { Nd(III): } \\
\text { Ions }\end{array}$ & $\begin{array}{l}\text { Amount } \\
\text { tolerated } \\
\quad(\mathrm{mg})\end{array}$ & Foreign ion \\
\hline $1: 833$ & 50 & Bromide, oxalate, citrate \\
\hline $1: 417$ & 25 & $\begin{array}{l}\text { Thiosulphate, acetate, } \\
\text { thiourea, tartrate, } \mathrm{Ca} \text { (II) }\end{array}$ \\
\hline $1: 250$ & 15 & Nitrate, iodide \\
\hline $1: 167$ & 10 & $\begin{array}{l}\text { Malonate, ascorbate, } \\
\text { fluoride, } \mathrm{Sr}(\mathrm{II}), \mathrm{Mg}(\mathrm{II})^{\mathrm{b}} \text {, } \\
\mathrm{Cr}(\mathrm{VI}), \mathrm{Sm}(\mathrm{III})\end{array}$ \\
\hline $1: 117$ & 7 & $\begin{array}{l}\text { Phosphate, nitrite, } \\
\text { W(VI), Cd(II), V(V })^{\mathrm{a}} \text {, } \\
\operatorname{Pd}(\mathrm{II})\end{array}$ \\
\hline $1: 83$ & 5 & $\begin{array}{l}\operatorname{Ti}(\mathrm{IV}), \mathrm{Y}(\mathrm{III})^{\mathrm{c}}, \mathrm{Nb}(\mathrm{V}) \\
\mathrm{Zr}(\mathrm{IV})^{\mathrm{a}}\end{array}$ \\
\hline $1: 50$ & 3 & Gd(III) \\
\hline $1: 33$ & 2 & $\mathrm{Ba}(\mathrm{II}), \mathrm{Zn}(\mathrm{II}), \mathrm{Co}(\mathrm{II})$ \\
\hline $1: 16$ & 1 & $\mathrm{Mo}(\mathrm{II}), \mathrm{Mn}(\mathrm{II})$ \\
\hline $1: 8$ & 0.5 & $\begin{array}{l}\mathrm{Fe}(\mathrm{II}), \mathrm{Ta}(\mathrm{V}), \mathrm{Ce}(\mathrm{IV}) \\
\mathrm{La}(\mathrm{III})\end{array}$ \\
\hline $1: 5$ & 0.3 & $\mathrm{Ni}(\mathrm{II}), \mathrm{U}(\mathrm{VI})$ \\
\hline
\end{tabular}

TABLE 6: Separation of neodymium(III) from binary mixtures.

\begin{tabular}{|c|c|c|c|}
\hline Metal ion & $\begin{array}{l}\text { Metal ion } \\
\text { added, } \\
(\mu \mathrm{g})\end{array}$ & $\begin{array}{c}\text { Average } \\
(\%) \\
\text { recovery* }\end{array}$ & $\begin{array}{c}\text { Chromogenic } \\
\text { ligand }\end{array}$ \\
\hline Nd(III) & 75 & 99.6 & PAR \\
\hline $\mathrm{U}(\mathrm{VI})$ & 50 & 98.7 & PAR \\
\hline $\mathrm{Nd}(\mathrm{III})$ & 75 & 99.8 & \\
\hline $\mathrm{Zr}(\mathrm{IV})$ & 150 & 99.7 & Alizarin Red S \\
\hline $\mathrm{Nd}(\mathrm{III})$ & 75 & 98.5 & \\
\hline $\mathrm{Nb}(\mathrm{V})$ & 50 & 98.6 & PAR \\
\hline Nd(III) & 75 & 99.8 & \\
\hline $\mathrm{La}(\mathrm{III})$ & 60 & 99.5 & Arsenazo I \\
\hline Nd(III) & 75 & 99.7 & \\
\hline $\operatorname{Th}(\mathrm{IV})$ & 50 & 99.5 & Arsenazo III \\
\hline $\mathrm{Nd}(\mathrm{III})$ & 75 & 99.7 & \\
\hline $\mathrm{Ce}(\mathrm{IV})^{\mathrm{a}}$ & 50 & 99.5 & Arsenazo III \\
\hline Nd(III) & 75 & 99.6 & \\
\hline $\mathrm{Y}(\mathrm{III})^{\mathrm{b}}$ & 150 & 99.5 & Alizarin Red S \\
\hline
\end{tabular}

${ }^{\mathrm{a}}$ Masked with $10 \mathrm{mg}$ fluoride, ${ }^{\mathrm{b}}$ masked with $50 \mathrm{mg}$ thiosulphate, and *average of six determinations.

demasking of Ce(IV) and Y(III) with $5 \mathrm{~mL}$ hydrochloric acid, the solution was evaporated to dryness. They were determined spectrophotometrically with Arsenazo III at $660 \mathrm{~nm}$ [24] and Alizarin Red S [20], respectively.
TABLE 7: Separation of neodymium(III) from synthetic mixture.

\begin{tabular}{|c|c|c|}
\hline $\begin{array}{l}\text { Composition, } \\
(\mu \mathrm{g})\end{array}$ & $\begin{array}{l}\text { Average } \\
(\%) \\
\text { recovery* }\end{array}$ & $\begin{array}{l}\text { Relative error, } \\
\qquad(\%)\end{array}$ \\
\hline $\begin{array}{l}\text { Nd(III) 60; } \\
\text { U(VI) 50; } \\
\text { Th(IV) } 50\end{array}$ & 99.6 & 0.4 \\
\hline $\begin{array}{l}\mathrm{Nd}(\mathrm{III}) 60 ; \\
\mathrm{La}(\mathrm{III}) 60 ; \\
\mathrm{Zr}(\mathrm{IV}) 150\end{array}$ & 99.5 & 0.5 \\
\hline $\begin{array}{l}\mathrm{Nd}(\mathrm{III}) 60 ; \\
\mathrm{Nb}(\mathrm{V}) 50 \\
\mathrm{Zr}(\mathrm{IV}) 150\end{array}$ & 99.7 & 0.3 \\
\hline $\begin{array}{l}\mathrm{Nd}(\mathrm{III}) 60 \\
\mathrm{Y}(\mathrm{III})^{\mathrm{a}} 150 \\
\mathrm{Nb}(\mathrm{V}) 50\end{array}$ & 99.5 & 0.5 \\
\hline \multicolumn{3}{|c|}{ aasked with 50 mg thiosulphate, *average of five determinations. } \\
\hline \multicolumn{3}{|c|}{$\begin{array}{l}\text { 4.2. Determination of Neodymium(III) in Synthetic Mixture. } \\
\text { The applicability of the developed method for separation and } \\
\text { determination of neodymium(III) in complex mixtures was } \\
\text { studied (Table 7). In the synthetic mixtures, neodymium(III) } \\
\text { was extracted under the optimum extraction conditions and } \\
\text { quantitatively recovered in all mixtures. }\end{array}$} \\
\hline
\end{tabular}

\section{Conclusion}

(i) Quantitative extraction of neodymium(III) was achieved in $5 \mathrm{~min}$ with $0.1 \mathrm{M} \mathrm{N}$ - $n$-octylaniline in xylene at $\mathrm{pH}$ 6.0.

(ii) The proposed extractive separation method is simple, rapid, selective, reproducible, and suitable for separation and determination of neodymium(III) from associated metal ions and synthetic mixtures.

(iii) Trace level of neodymium(III) extracted using low concentration of $\mathrm{N}-n$-octylaniline.

(iv) The extraction mechanism corresponds to an anion exchange, in which a complex of stoichiometric formula $\left[\mathrm{RR}^{\prime} \mathrm{NH}_{2}{ }^{+} \mathrm{Nd}(\text { succinate })_{2}{ }^{-}\right]_{\text {org }}$ is formed in the organic phase.

(v) It is free from the interference of a large number of foreign ions.

(vi) The solvent-like xylene showed good results for N-noctylaniline compared with other diluents used.

(vii) $\mathrm{N}$ - $n$-octylaniline can be synthesized at low cost, with high yield and best purity.

\section{Acknowledgments}

The authors are thankful to UGC-SAP and DST-FIST. One of the authors (B. N. Kokare) is thankful to UGC for providing financial assistance. 


\section{References}

[1] J. D. Lee, Concise Inorganic Chemistry, ELBS Chapman and Hall, London, UK, 4th edition, 1991.

[2] R. C. Vickary, Chemistry of Lanthanons, Butterworth's, 1953.

[3] C. R. Hammond, "The elements," in Handbook of Chemistry and Physics, CRC Press, 81th edition, 2000.

[4] Y. Wei and X. Zhou, "The effect of neodymium $\left(\mathrm{Nd}^{+3}\right)$ on some physiological activities in oilseed rape during calcium $\left(\mathrm{Ca}^{+2}\right)$ starvation," in Proceedings of the 10th International Rapeseed Congress, Canberra, Australia, 1999.

[5] I. L. Dukov and M. Atanassova, "Effect of the diluents on the synergistic solvent extraction of some lanthanides with thenoyltrifluoroacetone and quaternary ammonium salt," Hydrometallurgy, vol. 68, no. 1-3, pp. 89-96, 2003.

[6] M. Atanassova and I. L. Dukov, "Synergistic solvent extraction and separation of trivalent lanthanide metals with mixtures of 4-benzoyl-3-methyl-1-phenyl-2-pyrazolin-5-one and aliquat 336," Separation and Purification Technology, vol. 40, no. 2, pp. 171-176, 2004.

[7] M. Atanassova, "Synergistic solvent extraction and separation of lanthanide(III) Ions with 4-Benzoyl-3-Phenyl-5-Isoxazolone and the quaternary ammonium salt," Solvent Extraction and Ion Exchange, vol. 27, no. 2, pp. 159-171, 2009.

[8] M. L. P. Reddy, J. R. Bosco Bharathi, S. Peter, and T. R. Ramamohan, "Synergistic extraction of rare earths with bis (2,4,4-trimethyl pentyl) dithiophosphinic acid and trialkyl phosphine oxide," Talanta, vol. 50, no. 1, pp. 79-85, 1999.

[9] E. A. Mowafy and H. F. Aly, "Extraction behaviours of Nd(III), $\mathrm{Eu}(\mathrm{III}), \mathrm{La}(\mathrm{III}), \mathrm{Am}(\mathrm{III})$, and $\mathrm{U}(\mathrm{VI})$ with some substituted malonamides from nitrate medium," Solvent Extraction and Ion Exchange, vol. 20, no. 2, pp. 177-194, 2002.

[10] E. A. Mowafy and H. F. Aly, "Extraction behaviors of trivalent lanthanides from nitrate medium by selected substituted malonamides," Solvent Extraction and Ion Exchange, vol. 24, no. 5, pp. 677-692, 2006.

[11] Y. Koma, T. Koyama, and Y. Tanaka, "Enhancement of the mutual separation of lanthanide elements in the solvent extraction based on the CMPO-TBP mixed solvent by using a DTPAnitrate solution," Journal of Nuclear Science and Technology, vol. 36, no. 10, pp. 934-939, 1999.

[12] W. He, W. Liao, C. Niu, and D. Li, "Synergistic extraction of rare earths using acid-base coupling extractants of calyx[4] arene carboxyl derivative and primary amine N1923," Separation and Purification Technology, vol. 62, pp. 674-680, 2008.

[13] M. Atanassova, V. M. Jordanov, and I. L. Dukov, "Effect of the quaternary ammonium salt Aliquat 336 on the solvent extraction of lanthanoid (III) ions with thenoyltrifluoroacetone," Hydrometallurgy, vol. 63, no. 1, pp. 41-47, 2002.

[14] I. L. Dukov and M. Atanassova, "Effect of the diluents on the synergistic solvent extraction of some lanthanides with thenoyltrifluoroacetone and quaternary ammonium salt," Hydrometallurgy, vol. 68, no. 1-3, pp. 89-96, 2003.

[15] Q. Jia, Z. Li, W. Zhou, and H. Li, "Studies on the solvent extraction of rare earths from nitrate media with a combination of di(2-etylhexyl) phosphoric acid and sec-octylphenoxyacetic acid," Journal of Chemical Technology \& Biotechnology, vol. 84, pp. 565-569, 2009.

[16] M. S. Lee, J. Y. Lee, J. S. Kim, and G. S. Lee, "Solvent extraction of neodymium ions from hydrochloric acid solution using PC88A and saponified PC88A," Separation and Purification Technology, vol. 46, pp. 72-78, 2005.
[17] A. Hino, S. Nishihama, T. Hirai, and I. Komasawa, "Practical study of liquid-liquid extraction process for separation of rare earth elements with bis(2-ethylhexyl) phosphinic acid," Journal of Chemical Engineering of Japan, vol. 30, no. 6, pp. 10401046, 1997.

[18] M. S. Milyukova, N. S. Varezhkina, and B. F. Myasoedov, "Extraction of rare earth elements by high molecular weight amines from nitric acid solutions," Journal of Radioanalytical and Nuclear Chemistry Letters, vol. 105, no. 4, pp. 249-256, 1986.

[19] D. D. Desai and V. M. Shinde, "Liquid anion-exchange extraction and separation of yttrium, neodymium and samarium," Analytica Chimica Acta, vol. 167, pp. 413-417, 1985.

[20] E. B. Sandell, Colorimetric Determination of Traces of Metals, Interscience, New York, NY, USA, 3rd edition, 1965.

[21] Z. H. Gardlund, R. J. Curtis, and G. W. Smith, "Influence of molecular structural changes on the mesomorphic behavior of benzylideneanilines," Liquid Crystals Ordered Fluids, vol. 2, pp. 541-545, 1973.

[22] K. N. Munshi, "Spectrophotometric determination of rare earth metals with 4-(2-pyridylazo)resorcinol," Analytical Chemistry, vol. 36, no. 10, pp. 2003-2004, 1964.

[23] H. A. Flaschka and A. J. Barnard Jr., Chelates in Analytical Chemistry, vol. 4, Marcel Dekker, New York, NY, USA, 1972.

[24] Z. Marckzenko, Spectrophotometric Determination of Elements, Ellis Horwood Limited, Chichester, UK, 1st edition, 1976.

[25] S. Shibata, F. Takeuchi, and T. Matsumae, "Spectrophotometric determination of lanthanum with neo-thorone," Analytica Chimica Acta, vol. 21, pp. 177-181, 1959. 


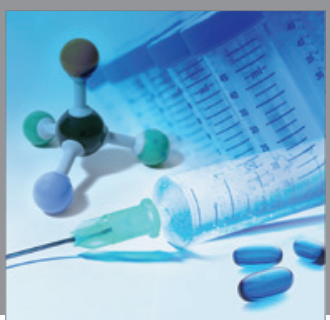

International Journal of

Medicinal Chemistry

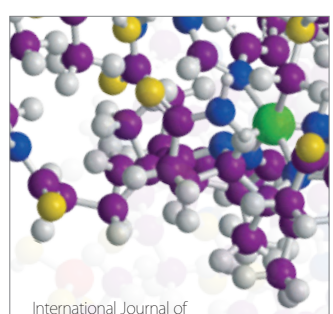

Carbohydrate Chemistry

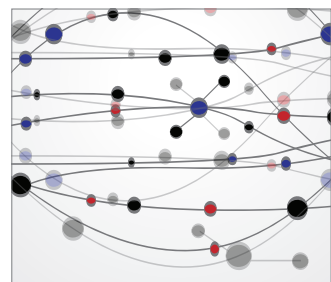

The Scientific World Journal
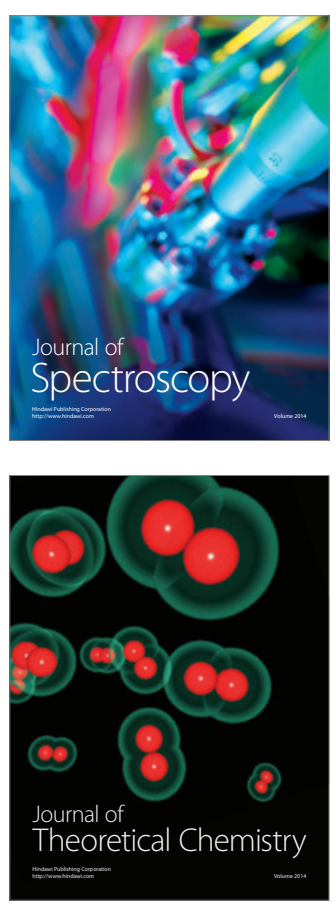
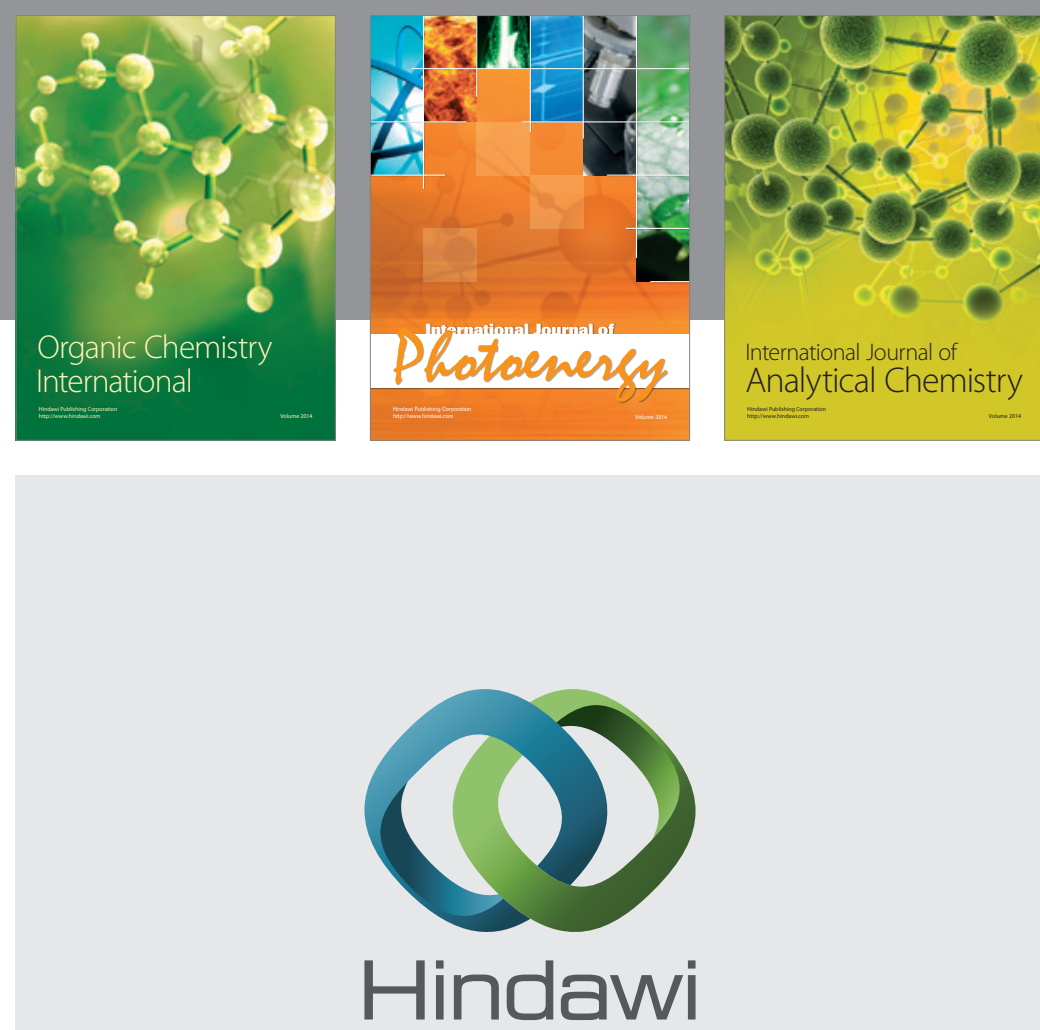

Submit your manuscripts at

http://www.hindawi.com
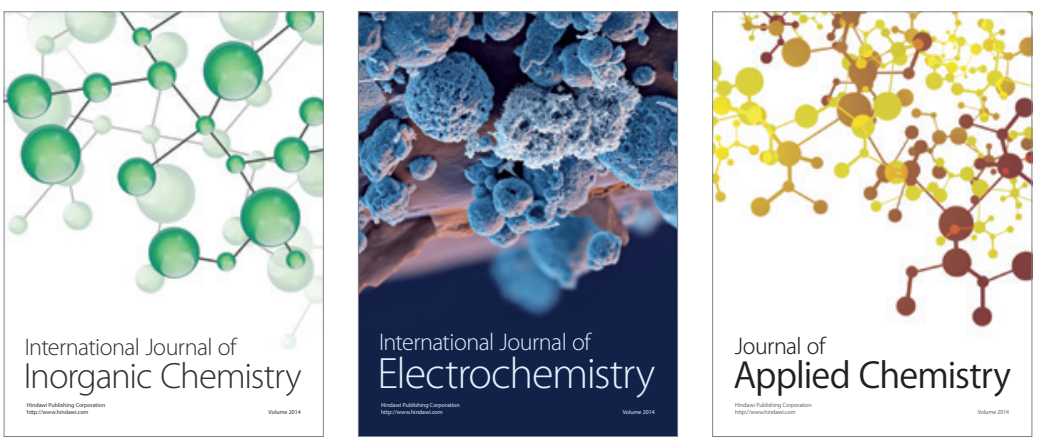

Journal of

Applied Chemistry
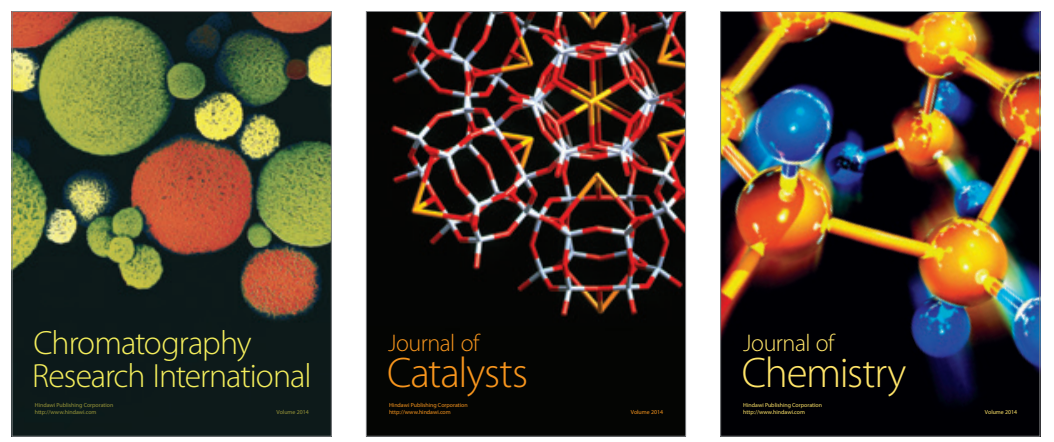
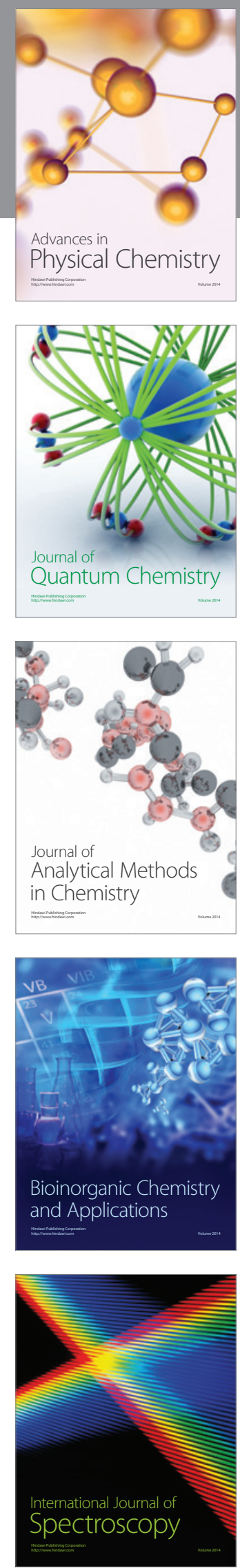